\title{
ANALISA LAJU PERPINDAHAN PANAS PADA KOLEKTOR SURYA TIPE PELAT DATAR DENGAN ABSORBER PASIR
}

\author{
Made Wirawan*, Rudy Sutanto*
}

* Dosen Jurusan Teknik Mesin Universitas Mataram NTB, JI. Majapahit No 62 Mataram

\begin{abstract}
Abstrack
Solar energy constitute one of potential alternative energy to develop as a back up of energy. Especially for countries in khatulistiwa location belonging to Indonesia. For use solar energy needful collector that using absorber. Using sand as a absorber make up step for increase value and profit of sand, in a economics manner the price more cheap and easy to obtain than another absorber. The analysis use sand as a alternative absorber for solar collector did for understand rate of heat transfer to acceptanceof water.

Dimention of collector are $560 \mathrm{~mm} \times 310 \mathrm{~mm}$ with thick of sand absorber $10 \mathrm{~mm}$ and $1.2 \mathrm{~mm}$ for aluminum plate as a comparator. Observation did begin $10.00 \mathrm{am}$ until $14.00 \mathrm{pm}$ for the two of them in the weather clear sky. The rate of water in this research are $200 \mathrm{cc} / \mathrm{min}, 250 \mathrm{cc} / \mathrm{min}$ and $300 \mathrm{cc} / \mathrm{mn}$ for another dan at the same time.

The result of analysis be obtained heat absortion by water for solar collector with aluminum absorber more large than sand absorber. The debit of water more and more large in the collector so absorb heat by water more large because incretion the mass flow rate of water $(\dot{m})$. The heat losses in the solar collector aluminum absorber more than sand absorber.
\end{abstract}

Key words : collector, sand and heat

\section{Latar Belakang}

Penggunaan energi dewasa ini semakin meningkat yang diakibatkan dengan semakin meningkatnya kebutuhan energi diberbagai bidang. Disisi lain persediaan energi fosil yang digunakan yaitu berupa bahan bakar minyak, gas bumi, dan batu bara jumlahnya terbatas dan tidak dapat diperbaharui sehingga jika kita terus mengeksplorasi secara terus-menerus bahan bakar fosil tersebut lama-kelamaan akan habis..

Energi surya merupakan salah satu energi alternatif yang potensial untuk dikelola dan dikembangkan lebih lanjut sebagai sumber cadangan energi terutama bagi negara-negara yang terletak di khatulistiwa termasuk Indonesia, dimana matahari bersinar sepanjang tahun. Energi surya bersifat renewable.adalah energi yang tidak polutif, bersifat kontinyu dan tidak dapat habis.

Energi surya yang memasuki atmosfer memiliki kerapatan daya rata-rata sebesar 1,2 $\mathrm{kW} / \mathrm{m}^{2}$, namun hanya sebesar $560 \mathrm{~W} / \mathrm{m}^{2}$ yang diserap bumi. Berdasarkan angka di atas, maka energi surya yang dapat dibangkitkan untuk seluruh daratan Indonesia yang mempunyai luas \pm 2 juta $\mathrm{km}^{2}$ adalah sebesar $5.10^{8} \mathrm{MW}$ (Santhiarsa,2005). Betapa melimpahnya energi yang sebagian besar terbuang sia-sia ini. Untuk memanfaatkan potensi energi surya tersebut, ada 2 (dua) macam teknologi yang sudah diterapkan, yaitu teknologi energi surya termal dan energi surya fotovoltaik. Untuk meningkatkan efektifitas pemanfaatan energi surya secara langsung, dapat dikembangkan dengan menggunakan pengumpul-pengumpul panas yang biasa disebut kolektor. Salah satu pemanfaatan kolektor surya adalah kolektor surya pemanas air.

Penggunaan pasir sebagai bahan absorber merupakan langkah untuk menambah nilai guna dan manfaat, secara ekonomis harga relatif murah dan mudah didapat dibandingkan dengan absorber yang ada pada saat ini. Analisa penggunaan pasir sebagai absorber alternatif pada kolektor surya dilakukan untuk mengetahui besar laju perpindahan panas yang diterima air dan dibandingkan dengan absorber pelat aluminium.

\section{Kolektor Surya}

Energi dari matahari tiba dibumi adalah dalam bentuk radiasi elektromagnetik. Rata-rata nilai dari pancaran surya dan (solar irradiance) diluar atmosfir bumi adalah $1353 \mathrm{~W} / \mathrm{m}^{2}$ tetapi karena melalui atmosfir, banyak energi yang terserap oleh molekul-molekul debu, molekulmolekul uap air dsb. Maka total energi yang sampai pada permukaan horizontal dibumi maksimum sekitar $1000 \mathrm{~W} / \mathrm{m}^{2}$ dan nilai tersebut disebut sebagai pancaran global (global irradiance). Global radiasi bervariasi karena beberapa faktor, antara lain : perubahan sudut penyinaran surya, panjang lintasan sinar yang dilalui di atmosfir, pergantian musim dan posisi garis lintang.

Komponen utama kolektor surya adalah cover yang berfungsi sebagai penutup kolektor yang transparan, absorber untuk menyerap 
energi dan mengkonversikaan energi matahari menjadi energi thermal, isolasi untuk menahan panas dalam kolektor dan saluran atau kanal untuk mengalirkan fluida yang membawa energi matahari. (Kalogirou, 2009)

Dengan asumsikan kolektor beroperasi pada kondisi steady state, yaitu sistem tidak berubah terhadap waktu. Panas yang di serap oleh air di dalam kolektor $\left(Q_{u}\right)$ adalah sama dengan perkalian dari kapasitas panas air pada tekanan konstan $\left(\mathrm{C}_{\mathrm{p}}\right)$, laju aliran masa air $(\dot{m})$ dan beda temperatur masuk dan temperatur keluar kolektor $\left(\mathrm{T}_{0}-\mathrm{T}_{\mathrm{i}}\right)$. Sehingga panas yang diserap oleh air $\left(Q_{u}\right)$ adalah

$$
Q_{u}=\dot{m} \cdot \mathrm{c}_{\mathrm{p}} \cdot\left(\mathrm{T}_{\mathrm{o}}-\mathrm{T}_{\mathrm{i}}\right)
$$

Apabila panas yang mampu diserap oleh air dinyatakan sebagai fluks panas yang dibagi dengan luasan $\mathrm{A}_{c}$ maka (Lunde, 1980)

$$
Q_{u} / A_{c} \equiv q
$$

\section{Dimana}

$Q_{u} \quad=$ Energi berguna yang dilepaskan oleh kolektor (Watt)

$\dot{m}$ = Laju aliran massa air (kg/s)

$\mathrm{c}_{\mathrm{p}}=$ Kapasitas panas air pada temperatur konstan.

$\mathrm{A}_{\mathrm{c}}=$ Luasan area kolektor $\left(\mathrm{m}^{2}\right)$

$\mathrm{T}_{0}=$ Temperatur outlet air rata-rata $\left({ }^{\circ} \mathrm{C}\right)$

$\mathrm{T}_{\mathrm{i}}=$ Temperatur inlet air rata-rata $\left({ }^{\circ} \mathrm{C}\right)$

Kerugian Kalor pada Kolektor Surya

Radiasi matahari yang mengenai permukaan kolektor, sebagian besar akan diserap dan dihantarkan ke fluida, dan merupakan energi yang digunakan. Namun dalam berbagai sistem, maka akan terjadi

$$
Q_{t, \text { absorber ke kaca penutup }}=\mathrm{A}_{\mathrm{c}} \mathrm{h}_{\mathrm{c}, \mathrm{p}-\mathrm{g}}\left(\mathrm{T}_{\mathrm{p}}-\mathrm{T}_{\mathrm{a}}\right)+\frac{\mathrm{A}_{\mathrm{c}} \sigma\left(\mathrm{T}_{\mathrm{p}}^{4}-\mathrm{T}_{\mathrm{g}}{ }^{4}\right)}{\left(1 / \epsilon_{p}\right)+\left(1 / \epsilon_{g}\right)-1}
$$

Dimana,

$\mathrm{A}_{\mathrm{c}} \quad=$ luasan absorber $\left(\mathrm{m}^{2}\right)$

$\mathrm{h}_{\mathrm{c}, \mathrm{p}-\mathrm{g}}=$ koefisien perpindahan kalor konveksi antara absorber dan kaca penutup $\left(\mathrm{W} / \mathrm{m}^{2} \mathrm{~K}\right)$

$\varepsilon_{\mathrm{p}}=$ emisifitas dari absorber

$\varepsilon_{\mathrm{g}} \quad=$ emisifitas dari kaca penutup kerugian energi. Kerugian energi dari kolektor, dituliskan:

$$
Q_{\text {loss }}=\frac{T_{p}-T_{a}}{R_{L}}=U_{L} A_{c}\left(T_{p}-T_{a}\right)
$$

$U_{L}=$ Koefisien kerugian kalor secara keseluruhan pada kolektor dengan luasan $\mathrm{A}_{\mathrm{c}}\left(\mathrm{W} / \mathrm{m}^{2}-\mathrm{K}\right)$

$\mathrm{T}_{\mathrm{p}}=$ Temperatur Pasir $\left({ }^{\circ} \mathrm{C}\right)$

$\mathrm{T}_{\mathrm{a}}=$ Temperatur Lingkungan $\left({ }^{\circ} \mathrm{C}\right)$ Koefisien kerugian kalor secara keseluruhan dituliskan,

$$
U_{L}=U_{t}+U_{b}+U_{e}
$$

Dimana $\left(\mathrm{W} / \mathrm{m}^{2}-\mathrm{K}\right)$

$U_{b}=$ koefisien kerugian panas bagian bawa $\left(\mathrm{W} / \mathrm{m}^{2}-\mathrm{K}\right)$

$\mathrm{U}_{\mathrm{e}}=$ koefisien kerugian panas dari samping kolektor $\left(\mathrm{W} / \mathrm{m}^{2}-\mathrm{K}\right)$

\section{Kerugian Kalor Atas}

Perpindahan panas dari absorber ke kaca penutup adalah sama dengan energi yang hilang dari kaca penutup ke lingkungan. Pada gambar 2.4 ditunjukkan, gerakan perpindahan panas ke atas dari absorber pada temperatur $T_{p}$ ke kaca penutup $T_{g}$ dan dari kaca penutup $T_{g}$ ke lingkungan $\mathrm{T}_{\mathrm{a}}$. .Ol kerugian panas dari absorber ke kaca adalah; 

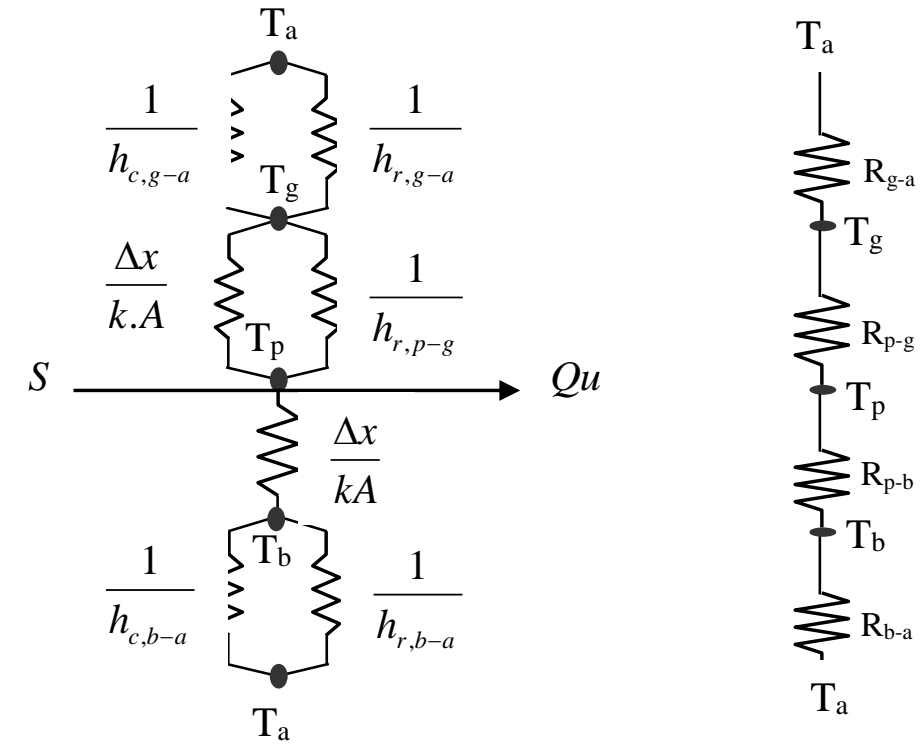

Gambar 1. Tahanan Thermal pada Kolektor Surya

Besar tahanan termal yang terjadi antara absorber dengan kaca pada kolektor terjadi secara konduksi dan radiasi. Perhitungan tahanan termal antara absorber dengan kaca dilakukan secara konduksi karena tidak ada aliran udara yang terjadi didalam kolektor. Besar tahanan termal konduksi anatara absorber dan kaca dapat dirumuskan sebagai berikur :

$$
R_{k, p-g}=\frac{\Delta x}{k A}
$$

Dengan $\Delta x$ merupakan jarak antara pelat ke kaca.

Koefisien kergian kalor radiasi yang terjadi antara pelat dan kaca dapat dirumuskan

$h_{r, p-g}=\frac{\sigma\left(T_{p}+T_{g}\right)\left(T_{p}^{2}+T_{g}^{2}\right)}{\left(1 / \varepsilon_{p}\right)+\left(1 / \varepsilon_{g}\right)-1}$

Maka rumus kerugian panas absorber ke kaca menjadi

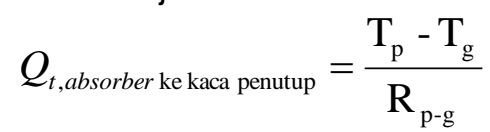

Dimana

$$
R_{p-g}=R_{k, \mathrm{p}-\mathrm{g}}+\frac{1}{A_{c} \cdot h_{r, \mathrm{p}-\mathrm{g}}}
$$

Kerugian panas yang hilang dari kaca ke lingkungan di rumuskan $\mathrm{h}_{\mathrm{r}, \mathrm{g}-\mathrm{a}}=$ koefisien perpindahan kalor radiasi antara kaca dan lingkungan $\left(\mathrm{W} / \mathrm{m}^{2} . \mathrm{K}\right)$

Koefisien perpindahan kalor radiasi diantara kaca ke lingkungan dirumuskan

$$
h_{r, g-a}=\varepsilon_{g} \sigma\left(T_{g}+T_{a}\right)\left(T_{g}^{2}+T_{a}^{2}\right)
$$

dan koefisen perpindahan kalor konveksi antara kaca dan lingkungan ditulis menurut Swinbank (Kalogirou, 2009)

$\mathrm{h}_{\mathrm{c}, \mathrm{g}-\mathrm{a}}=\mathrm{h}_{w}=5,7+3,8 \mathrm{v}$

Dimana $v=$ kecepatan angin $\left(\mathrm{m}^{2} / \mathrm{s}\right)$

2. Kerugian Kalor Bawah

Pada gambar tahanan thermal diatas energi yang hilang di bagian bawah kolekor di perlihatkan oleh dua tahanan seri yaitu $R_{p-b}$ dan $R_{b-a}$. Dimana $R_{p-b}$ menunjukkan tahanan aliran panas yang mengalir ke isolasi dan $R_{b-a}$ menunjukkan tahanan konveksi dan radiasi ke lingkungan. Koefisien kerugian panas bawah dapat diperkirakan sebagai berikut:

$$
U_{b}=\frac{1}{R_{b-a}}=\frac{k}{L}
$$

Dimana $k$ dan $\mathrm{L}$ adalah konduktifitas dan ketebalan isolasi..

3. Kerugian Kalor Samping

Kerugian panas pada bagian samping diasumsikan satu dimensi dimana aliran panas menyamping disekitar kolektor. Kerugian panas pada bagian sisi mengacu pada luasan absorber. Jika koefisien area kerugian panas (UA) edge, sehingga kerugian panas tepi berdasarkan luas absorber dirumuskan $Q_{t, \text { kaca penutup ke lingkungan }}=\mathrm{A}_{\mathrm{c}}\left(\mathrm{h}_{\mathrm{c}, \mathrm{g}_{\mathrm{g}} \mathrm{a}}+\mathrm{h}_{\mathrm{r}, \mathrm{g}-\mathrm{a}}\right)\left(\mathrm{T}_{\mathrm{g}}-\mathrm{T}_{\mathrm{a}}\right)=\frac{\mathrm{T}_{\mathrm{g}}-\mathrm{T}_{\mathrm{a}}}{\mathrm{R}_{\mathrm{g}-\mathrm{a}}} \quad \begin{gathered}\text { Kalogirou, 2009), } \\ (U A)_{\text {edge }}\end{gathered}$
$U_{e}=\frac{(10)}{A_{c}}$ $\mathrm{h}_{\mathrm{c}, \mathrm{g}-\mathrm{a}}=$ koefisien perpindahan kalor konveksi antara kaca dan lingkungan $\left(\mathrm{W} / \mathrm{m}^{2} . \mathrm{K}\right)$

\section{METODE PENELITIAN}


Pada rancang bangun kolektor ini. Tebal isolasi pada bagian bawah kolektor sebesar $50 \mathrm{~mm}$ dan tebal pada bagian samping kolektor adalah $20 \mathrm{~mm}$. Susunan dan dimensi peralatan kolektor surya dengan absorber pasir, dimana ketebalan pasir $10 \mathrm{~mm}$ dan kolektor surya dengan absorber plat aliminium dengan tebal 1,2 $\mathrm{mm}$ ditunjukkan pada gambar dibawah ini.

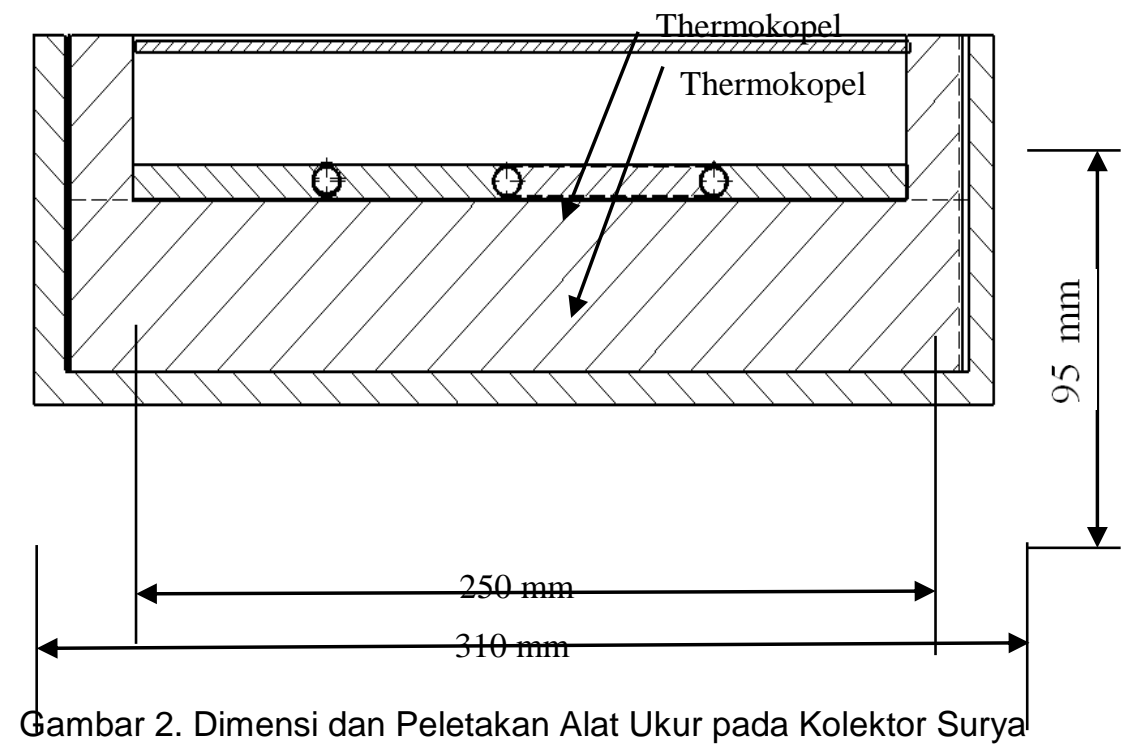

1. Kerangka kolektor surya dari kayu dan papan dengan panjang $=560 \mathrm{~mm}$ dan lebar $=310 \mathrm{~mm}$

2. Glass Cover yang digunakan berupa kaca bening dengan tebal $=3 \mathrm{~mm}$.

3. Material absorber dari pelat Aluminium dengan ketebalan 1,2 mm dicat hitam buram (dof).

4. Pipa cairan menggunakan bahan tembaga dengan diameter $3 / 8$ inchi $(9,525 \mathrm{~mm})$ dan dibuat menjadi tiga haluan dengan jarak antar haluan $62,5 \mathrm{~mm}$.

5. Bahan isolator yaitu sterofoam dengan tebal $50 \mathrm{~mm}$ di bagian bawah dan $20 \mathrm{~mm}$ di bagian depan dan samping kolektor.

6. Fluida yang digunakan adalah air.

pengamatan untuk dilakukan mulai jam 10.00 sampai dengan jam 14.00 pada kedua kolektor dalam kondisi cuaca cerah dan debit aliran air adalah $200 \mathrm{cc} / \mathrm{min} 250 \mathrm{cc} / \mathrm{min}$ dan 300 $\mathrm{cc} / \mathrm{min}$ pada hari berikutnya pada jam yang sama.

\section{Pembahasan}

jumlah kalor yang diserap oleh air pada kolektor surya dengan penggunaan absorber pelat maupun absorber pasir dengan variasi debit aliran $200 \mathrm{cc} /$ menit, $250 \mathrm{cc} /$ menit dan 300 $\mathrm{cc} /$ menit ditunjukkan berturut - turut pada grfik 1 , grafik 2 dan grafik 3 .

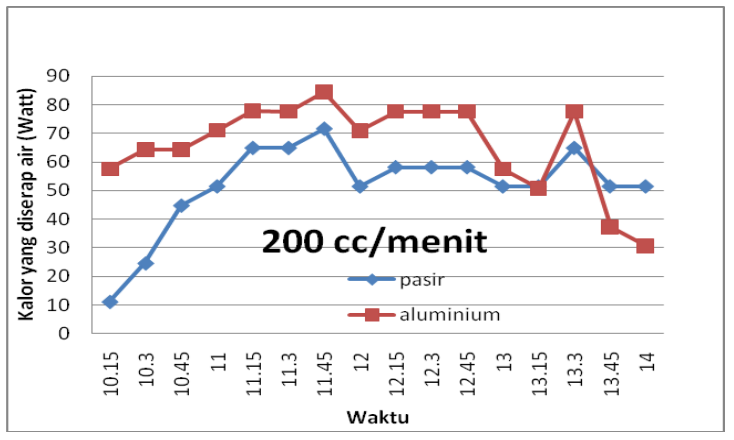

Grafik 1. besar kalor yang diserap air terhadap waktu pengamatan

Pada debit aliran $200 \mathrm{cc} /$ menit untuk kolektor surya absorber pelat maupun absorber pasir.

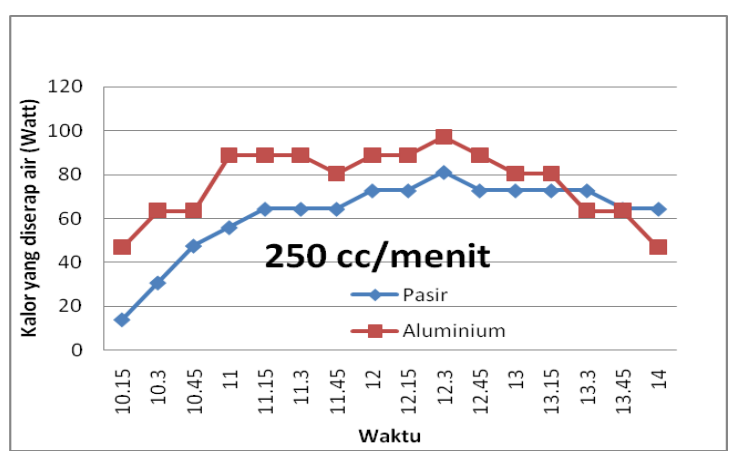

Grafik 2. besar kalor yang diserap air terhadap waktu pengamatan Pada debit aliran 250 $\mathrm{cc} /$ menit untuk kolektor surya absorber pelat maupun absorber pasir. 


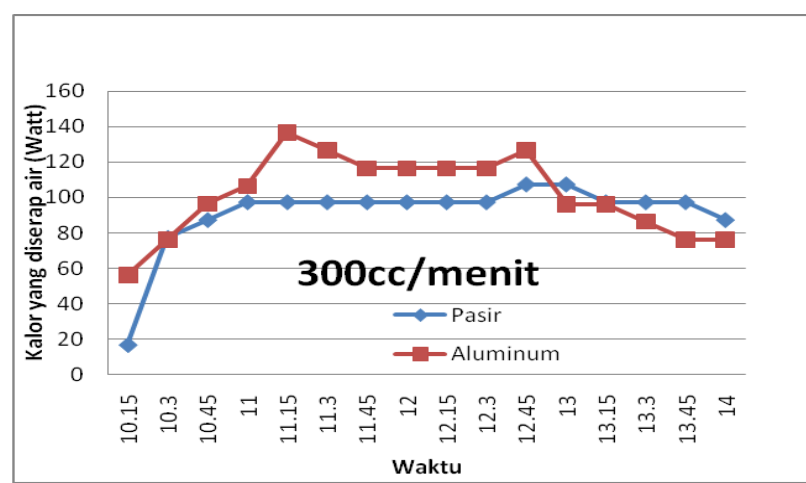

Grafik 3. besar kalor yang diserap air terhadap waktu pengamatan

Pada debit aliran $300 \mathrm{cc} /$ menit untuk kolektor surya absorber pelat maupun absorber pasir.

Berdasarkan grafik pada grafik 1 . sampai grafik 3 . dapat dilihat adanya kecendrungan peningkatan nilai kalor yang dapat diserap oleh air seiring dengan peningkatan jam penelitian. Hal ini disebabkan karena semakin lama waktu penelitian maka semakin banyak kalor yang dapat diserap oleh absorber, sehingga panas yang dapat didistribusikan ke air akan semakin besar.

Dari grafik pada grafi1, 2 dan 3, besar kalor yang digunakan untuk menaikkan temperatur air pada kolektor surya dengan absorber pelat lebih besar dari pada kolektor surya absorber pasir. Kolektor surya absorber pelat lebih banyak menyerap kalor yang diterimanya dibanding kolektor surya absorber pasir. Hal ini dapat dilihat dari perbedaan temperatur permukaan absorber antara kedua kolektor. Pada debit aliran $200 \mathrm{cc} /$ menit temperatur absorber pelat tertinggi mencapai $80,09{ }^{\circ} \mathrm{C}$ dan absorber pasir mencapai 64,19 ${ }^{\circ} \mathrm{C}$. Pada debit aliran $250 \mathrm{cc} /$ menit temperatur absorber pelat tertinggi mencapai $80,86{ }^{\circ} \mathrm{C}$ dan absorber pasir mencapai $61,14{ }^{\circ} \mathrm{C}$. Pada debit aliran $300 \mathrm{cc} /$ menit temperatur absorber pelat tertinggi mencapai $74,52^{\circ} \mathrm{C}$ dan absorber pasir mencapai $59,90^{\circ} \mathrm{C}$. Hal ini menunjukkan bahwa semakin besar temperatur permukaan sistem maka semakin besar energi yang diserap oleh kolektor sehingga energi kalor yang digunakan untuk menaikkan temperatur air semakin besar.

Pada kolektor dengan absorber pasir proses perpindahan kalor melalui pipa tembaga terjadi lebih lama, hal ini disebabkan karena panas yang diterima dari matahari di gunakan untuk memanaskan pasir tu sendiri sehingga laju perpindahan panas yang diterima oleh air menjadi lebih rendah dan panas yang diterima oleh pasir tidak dapat ditransfer secara maksimal ke pipa tembaga. Berbeda dengan kolektor surya absorber pelat aluminium. Panas yang diterima oleh absorber langsung digunakan, sehingga laju perpindahan kalor yang diterima air jauh lebih tinggi dan perbedaan kenaikan temperatur air juga lebih besar. Hal ini menunjukkan bahwa konduktifitas termal memiliki pengaruh yang sangat besar terhadap besar kalor yang dapat ditransfer oleh absorber untuk menaikkan temperatur air pada kolektor.

Dari grafik pada grafik1, 2 dan 3, pada saat kolektor menerima panas maksimum yaitu antara pukul 11.00-13.00. Pada kecepatan 200 $\mathrm{cc} / \mathrm{menit}$, kalor yang diserap oleh air pada kolektor surya absorber pelat mengalami penurunan yang lebih besar mengikuti penurunan dan peningkatan penyinaran yang diterima kolektor, pada pukul 12.15-12.45 kolektor surya absorber pasir cenderung stabil yaitu sebesar 77,518 Watt. Pada kecepatan 250 $\mathrm{cc} /$ menit, pada pukul 11.15-13.00 kolektor surya absorber pelat mengalami penurunan yang lebih besar mengikuti penurunan dan peningkatan penyinaran yang diterima kolektor, pada pukul 11.15-13.15 kolektor surya absorber pasir cenderung stabil yaitu sebesar 72,702 Watt. Pada kecepatan $300 \mathrm{cc} /$ menit, pada pukul 11.15-13.00 kolektor surya absorber pelat mengalami penurunan yang lebih besar mengikuti penurunan dan peningkatan penyinaran yang diterima kolektor, pada pukul 11.15-13.30 kolektor surya absorber pasir cenderung stabil walaupun terjadi peningkatan dan penururnan penyinaran yang diterima kolektor yaitu pukul 11.00-12.30 sebesar 97,311 Watt dan pada pukul 12.45-13.00 sebesar 107,377 Watt. Hal ini menunjukkan bahwa pada kolektor surya absorber pelat aluminium dan absorber pasir menunjukkan bahwa besar penyinaran matahari yang diterima kolektor sangat berpengaruh terhadap energi kalor yang digunakan pada kedua kolektor. Energi kalor yang diserap oleh air semakin besar pada saat penyinaran matahari yang diterima semakin besar sehingga perubahan kalor yang digunakan pada kedua kolektor mengikuti perubahan penyinaran matahari. Hal ini juga menunjukkan sedikit terjadi penurunan panas yang diterima pada kolektor surya dengan absorber pasir, karena pasir menggunakan panas yang masih tersimpan, sehingga laju aliran panas yang diterima oleh kolektor sedikit menurun. Hal ini dapat dilihat dari kalor yang digunakan cendrung stabil baik pada kecepatan $200 \mathrm{cc} /$ menit, $250 \mathrm{cc} /$ menit dan $300 \mathrm{cc} /$ menit. Berbeda dengan absorber pelat aluminium, terjadi penurunan panas yang diserap oleh absorber lebih besar. Peningkatan dan penurunan panas yang digunakan untuk menaikkan temperatur air mengikuti perubahan penyinaran matahari yang diterima kolektor. Jumlah kalor yang diserap air dengan variasi debit aliran $200 \mathrm{cc} /$ menit, $250 \mathrm{cc} /$ menit dan $300 \mathrm{cc} /$ menit dengan penggunaan absorber pasir ditunjukkan pada grafik 4 . 


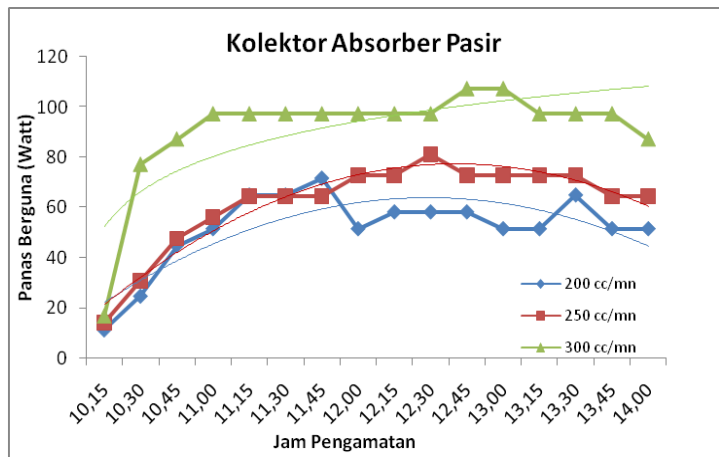

Grafik 4. kalor yang diserap oleh air terhadap waktu pengamatan pada debit aliran 200 $\mathrm{cc} /$ menit, $250 \mathrm{cc} / \mathrm{menit}$ dan $300 \mathrm{cc} /$ menit pada kolektor surya absorber pasir.

Dari grafik 4. Menunjukkan bahwa perubahan debit air pada masing-masing kolektor juga mempengaruhi kalor yang diserap oleh air. Kalor yang paling besar diserap oleh kolektor terjadi pada debit aliran $300 \mathrm{cc} /$ menit kemudian $250 \mathrm{cc} /$ menit dan $200 \mathrm{cc} /$ menit. Dari analisa data menggunakan persamaan untuk mengetahui laju aliran massa air $(\dot{m})$, dapat dianalisa bahwa dengan bertambahnya debit dari $200 \mathrm{cc} /$ menit , $250 \mathrm{cc} /$ menit menjadi 300 cc/menit akan menyebabkan laju aliran massa air $(\dot{m})$ bertambah. Bertambahnya laju aliran massa air menyebabkan kalor yang dapat diserap oleh air bertambah, dimana laju aliran massa air $(\dot{m})$ berbanding lurus dengan kalor yang dapat diserap air.

Dari grafik 4. juga menunjukkan bahwa penyinaran mencapai maksimum antara pukul 11.00 - 13.00. Besar sinar datang yang masuk kolektor menempuk jarak yang lebih dekat sehingga intensitas matahri menjad lebih besar. Besarnya temperatur pasir tergantung dari besar penyinaran matahari, kontinuitas penyinaran yang diterima oleh pasir. Semakin besar penyinaran matahari yang menyinari absorber, maka energi yang diserap untuk menaikkan temperatur pasir semakin besar. Temperatur fluida keluar mengikuti perubahan temperatur absorber, karena fluida yang dipanaskan sangat tergantung dari besarnya temperatur absorber yang merupakan sumber kalor untuk menaikkan temperaturnya. Dengan meningkatnya penyinaran matahari, maka temperatur pasir penyerap akan semakin tinggi, sehingga kalor yang dipindahkan ke fluida juga meningkat, sehingga peningkatan jumlah kalor yang dipindahkan ke fluida akan meningkatkan temperatur keluaran fluida.

\section{Analisa Kerugian Kalor Antara Kolektor Surya Absorber Pelat Dengan Kolektor Surya Absorber Pasir.}

Besarnya kerugian kalor pada kolektor surya dengan penggunaan absorber pelat maupun absorber pasir pada variasi debit aliran

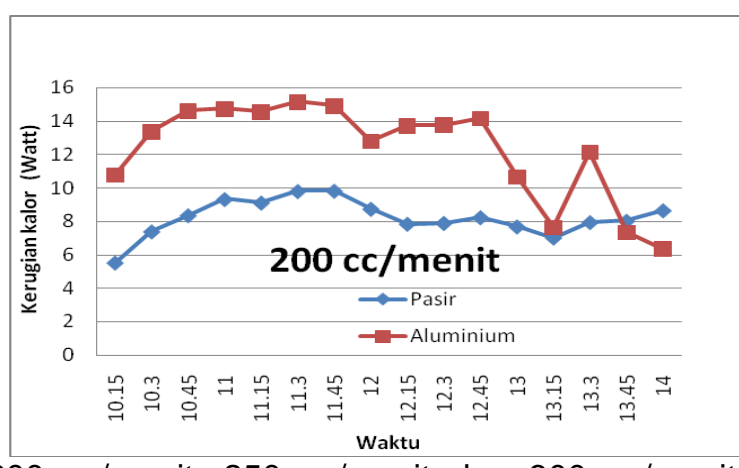

$200 \mathrm{cc} /$ menit, $250 \mathrm{cc} /$ menit dan $300 \mathrm{cc} / \mathrm{menit}$ ditunjukkan pada grafik 5 dan 7 .

Grafik 5. kerugian kalor terhadap jam pengamatan antara kolektor surya absorber pelat dan absorber pasir pada debit aliran 200 $\mathrm{cc} /$ menit.

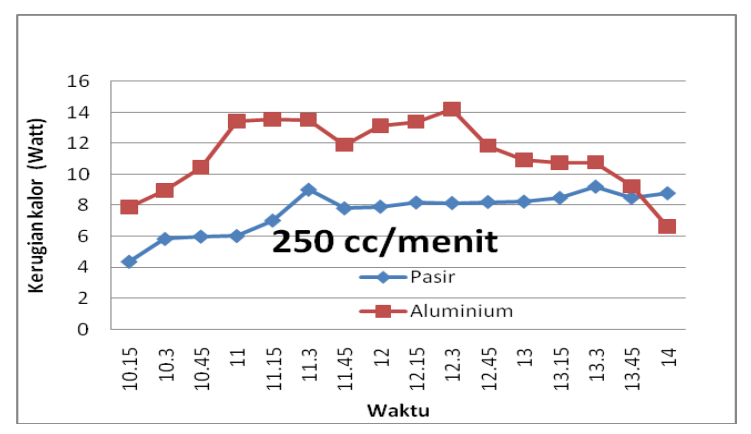

Grafik 6. kerugian kalor terhadap jam pengamatan antara kolektor surya absorber pelat dan absorber pasir pada debit aliran 250 $\mathrm{cc} /$ menit.

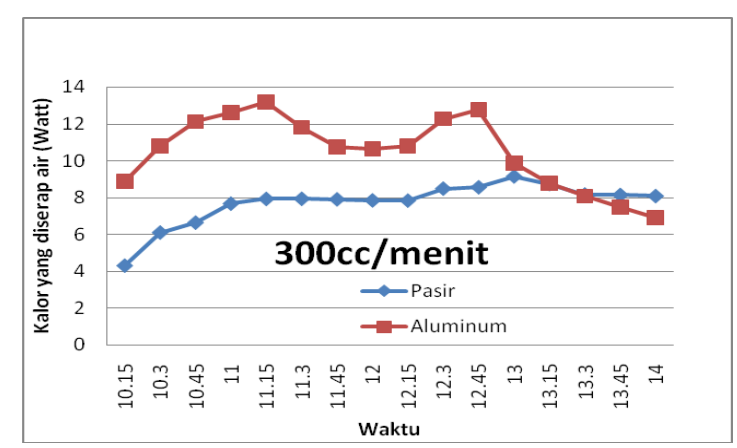

Grafik 7. kerugian kalor terhadap jam pengamatan antara kolektor surya absorber pelat dan absorber pasir pada debit aliran 300 $\mathrm{cc} /$ menit.

Dari grafik 5, 6 dan 7, terlihat perbedaan kerugian kalor yang dilepas antara kedua kolektor. Kerugian kalor yang dialami kolektor surya absorber pasir lebih rendah dibandingkan dengan kolektor surya absorber pelat. Hal ini disebabkan perbedaan temperatur kolektor surya yang diwakili oleh temperatur pelat dan temperatur cover. Pada debit aliran $200 \mathrm{cc} /$ menit temperatur absorber pelat tertinggi mencapai $80,09{ }^{\circ} \mathrm{C}$ dan absorber pasir mencapai $64,19{ }^{\circ} \mathrm{C}$. Pada debit aliran 250 $\mathrm{cc} /$ menit temperatur absorber pelat tertinggi mencapai $80,86{ }^{\circ} \mathrm{C}$ dan absorber pasir 
mencapai $61,14{ }^{\circ} \mathrm{C}$. Pada debit aliran 300 $\mathrm{cc} /$ menit temperatur absorber pelat tertinggi mencapai $74,52{ }^{\circ} \mathrm{C}$ dan absorber pasir mencapai $59,90^{\circ} \mathrm{C}$. Hal ini menunjukkan bahwa semakin besar temperatur permukaan sistem maka semakin besar kerugian kalor yang terjadi sehingga energi kalor yang digunakan untuk menaikkan temperatur air semakin rendah. Besar kerugian kalor pada kolektor juga dipengaruhi oleh perubahan penyinaran matahari yang diterimanya. Semakin besar penyinaran matahari yang diterima kolektor maka semakin besar kerugian kalor yang terjadi. $\mathrm{Hal}$ ini menyebabkan peningkatan beda temperatur antara absorber dan lingkungan menjadi lebih besar.

Pada kolektor surya absorber pasir cenderung terjadi peningkatan kerugian kalor yang terjadi pada saat peningkatan dan penurunan penyinaran energi matahari yang digunakan oleh kolektor. Hal ini dapat dilihat pada grafik pada grafik 5,6 dan 7 pada kecepatan $200 \mathrm{cc} /$ menit, $250 \mathrm{cc} /$ menit dan 300 $\mathrm{cc} /$ menit, kerugian kalor pada absorber pasir cenderung mengalami peningkatan kerugian kalor. Hal ini disebabkan energi panas yang dimiliki oleh absorber pasir masih tinggi karena adanya energi panas yang masih tersimpan, sehingga beda temperatur antara absorber yang diwakili oleh temperatur pasir terhadap lingkungan masih tinggi. Hal ini berbeda dengan kolektor surya absorber pelat. Penurunan dan peningkatan kerugian kalor akan mengikuti penurunan dan peningkatan penyinaran matahari yang diterima kolektor. Sehingga kerugian kalor mengikuti besar penyinaran matahari yang diterima kolektor.

Pada saat terjadi penurunan penyinaran matahari yang diterima oleh kolektor yaitu antara pukul 13.30-14.00, pada ketiga

\section{DAFTAR PUSTAKA}

Adi S. M. Abdul Jabbar., 2006 ; Analisis Thermal Kolektor Surya Pemanas Air Jenis Plat Datar Dengan Pipa Sejajar, Tugas Akhir, Universitas Muhamadiyah Surakarta-Surakarta

Bejan. Adrian., 1993, Heat Tansfer, John Wiley \& Sons Inc., New York.

Duffie. John A. and Beckman. William A., 1980 ; Solar Engineering Of Thermal Process $2^{\text {nd }}$ Edition, John Wiley \& Sons Inc., New York.

Handoyo. Ekadewi Anggraini.,2001 ; Pengaruh Jarak Kaca Ke Plat Terhadap Panas Yang Diterima Suatu Kolektor Surya Plat Datar, Jurnal Teknik Mesin Vol. 3, No. 2, Oktober: 52 - 56,Universitas Kristen Petra.

Kalogirou. Soteris., 2009 ; Solar Energy Engineering: Processes and Systems $1^{\text {st }}$ Edition, British Library, USA. debit aliran yaitu $200 \mathrm{cc} /$ menit, $250 \mathrm{cc} /$ menit dan $300 \mathrm{cc} /$ menit, kolektor surya absorber pelat mengalami penurunan kerugian kalor mengikuti penurunan kalor yang diserap sistem sehingga kerugian kalor yang terjadi menjadi lebih rendah. $\mathrm{Hal}$ ini berbeda dengan kolektor surya absorber pasir, kerugian kalor yang terjadi menjadi lebih besar, dipengaruhi oleh temperatur sistem yang masih tinggi karena adanya kalor yang tersimpan pada absorber sehingga beda temperatur antara sistem dengan terjadinya penurunan temperatur lingkungan menjadi lebih besar sehingga kerugian kalor menjadi lebih besar.

Harga Qu maksimum dicapai pada periode pengukuran yang memiliki penyinaran matahari maksimum, karena besar energi panas yang dapat dimanfaatkan bertambah, maka besar energi yang digunakan akan semakin tinggi.

\section{Kesimpulan}

Dari hasil penelitian dan pembahasan yang telah diperoleh, maka dapat ditarik kesimpulan sebagai berikut :

1. Kalor yang diserap oleh air pada kolektor surya absorber pelat aluminium lebih besar dibandingkan dengan kolektor surya absorber pasir

2. Semakin besar debit aliran air yang mengalir dalam kolektor maka kalor yang diserap oleh air semakin besar karena meningkatnya laju aliran massa air $(\dot{m})$.

3. Kerugian kalor yang dialami oleh kolektor surya absorber pelat aluminium lebih tinggi dibandingkan dengan kolektor surya absorber pasir.

Kristanto. Philip., dan San.Yoe Kim.,2001; Pengaruh Tebal Pelat dan Jarak antar Pipa Terhadap Performansi Kolektor Surya Pelat Datar, Jurnal Teknik Mesin Fakultas Teknik Industri Universitas Petra, Vol 3 No 2, Oktober 47-51

Lunde. Peter J., 1980 ; Solar Thermal Engineering Space Heating and Hot Water System, Jhon Wiley \& Sons Inc, New York Marbun. Nesten M., 2009 ; Rancang bangun Sebuah Pemanas Air Tenaga Surya dengan Menggunakan Kolektor Surya Plat Datar, Karya Akhir, Universitas Sumatra Utara-Medan.

Muharto., Ana Dwi Astuti.,dan Veny luvita.,2004 ; Efektivitas Penyerapan Panas Sinar Matahari Oleh Air Yang Mengalir Dalam Pipa, Jurusan Teknik Kimia FTI-ITS-Surabaya 